\title{
Safety of 5-Aminosalicylic Acid Derivatives in Patients with Sensitivity to Acetylsalicylic Acid and Nonsteroidal Anti-inflammatory
} Drugs

\author{
Jennifer Poh and Sandra Knowles
}

\begin{abstract}
Background: One of the cornerstones of the management of inflammatory bowel disease is the use of 5-aminosalicylic acid (5-ASA) compounds for treatment of flares and as maintenance therapy during remission. There are concerns about using 5-ASA in patients with a history of hypersensitivity to acetylsalicylic acid (ASA).

Objective: To assess the literature with respect to the safety of 5-ASA compounds in patients with documented sensitivity to ASA or nonsteroidal anti-inflammatory drugs (NSAIDs).

Data Sources: A literature search was conducted in the MEDLINE and Embase databases, using various search terms, including "aminosalicylic acids", "non-steroidal anti-inflammatory agents," "hypersensitivity", and "allergy". The search was limited to articles (of any study design) published in English. Abstracts, full articles, and reference lists from retrieved articles were assessed to identify further relevant literature.
\end{abstract}

Study Selection and Data Extraction: Of 485 citations identified in the initial search, 4 case reports were relevant to the study objective and were analyzed in detail.

Data Synthesis: Three of the case reports described the successful use of 5-ASA compounds in patients with prior sensitivity to ASA or an NSAID. The fourth report described a reaction to 5-ASA in a patient who had previously tolerated ASA. All of the reports were limited by lack of investigation into the validity of the reported sensitivity to ASA or 5-ASA.

Conclusions: There is a dearth of evidence demonstrating crossreactivity between ASA or NSAID and 5-ASA. This lack of information may relate to the mechanism of action of 5-ASA. This agent controls inflammation by inhibiting prostaglandin E2 and leukotrienes. In contrast, ASA-induced or NSAID-induced reactions are due to inhibition of the cycloxygenase-1 enzyme and subsequent release of histamine and synthesis of leukotrienes. Further reports describing the safety of 5-ASA use in patients with sensitivity to ASA or NSAIDs are needed before safety in this situation can be definitively determined. In patients with sensitivity to ASA or NSAID who require 5-ASA, a test dose of 5-ASA (to rule out potential cross-reactivity) or further investigation of the ASA or NSAID sensitivity is recommended.

\section{RÉSUMÉ}

Contexte : L'un des éléments essentiels du traitement des maladies inflammatoires de l'intestin est l'utilisation de préparations d'acide 5-aminosalicylique (5-ASA) pour traiter les poussées inflammatoires et comme traitement d'entretien pendant la rémission. En revanche, certaines inquiétudes existent quant à l'utilisation de préparations de 5-ASA chez les patients qui présentent une hypersensibilité à l'acide acétylsalicylique (AAS).

Objectif : Analyser la littérature portant sur l'innocuité des préparations de 5-ASA chez les patients qui souffrent d'une sensibilité attestée à l'AAS ou aux anti-inflammatoires non stéroïdiens (AINS).

Sources des données : Une recherche documentaire a été effectuée dans les bases de données MEDLINE et Embase. Les termes utilisés pour la recherche comprenaient entre autres : "acides aminosalicyliques ", " anti-inflammatoires non stéroïdiens ", « hypersensibilité » et " allergie ». La recherche se limitait aux articles publiés en anglais, sans égard au plan de l'étude. Les résumés, les articles complets et les listes de références des articles recensés ont été évalués afin de repérer toute autre littérature pertinente.

Sélection des études et extraction des données : Des 485 articles recensés lors de la recherche initiale, quatre observations cliniques étaient applicables à l'objectif de la présente étude et ont été examinées en détail.

Synthèse des données : Trois des quatre observations cliniques décrivaient une utilisation positive de préparations de 5-ASA chez des patients ayant des antécédents de sensibilité à l'AAS ou à un AINS. La quatrième observation rendait compte d'une réaction au 5-ASA chez un patient n'ayant jamais eu d'intolérance à l'AAS auparavant. L'ensemble de ces observations cliniques présentait des lacunes découlant de l'absence de vérification quant à la validité de la sensibilité à l'AAS ou au 5-ASA qui avait été signalée.

Conclusions : Il existe très peu de données permettant de démontrer la réactivité croisée entre l'AAS ou les AINS et les préparations de 5-ASA. Ce manque d'information peut avoir comme source le mécanisme d'action du 5-ASA. La capacité de ce dernier à réduire l'inflammation réside dans son pouvoir d'inhibition de la production de la prostaglandine E2 et de leucotriènes, un mécanisme différent de celui qui cause les réactions produites par l'AAS ou les AINS, car ces médicaments inhibent l'enzyme cyclo-oxygénase-1 et subséquemment la libération d'histamine et la synthèse de leucotriènes. D'autres observations décrivant l'innocuité 
Keywords: 5-ASA, acetylsalicylic acid, nonsteroidal anti-inflammatory drug, hypersensitivity du 5-ASA chez les patients présentant une sensibilité à l'AAS ou aux AINS doivent être effectuées avant de pouvoir déterminer définitivement si l'emploi de préparations de 5-ASA est sûr chez ces patients. Chez les patients qui souffrent d'une sensibilité à l'AAS ou aux AINS, il est recommandé d'administrer une dose d'essai de 5-ASA (afin d'exclure une réaction croisée possible) ou de vérifier plus soigneusement leur sensibilité à l'AAS ou aux AINS.

Mots clés : 5-ASA, acide acétylsalicylique, anti-inflammatoires non stéroïdiens, hypersensibilité

[Traduction par l'éditeur]

\section{INTRODUCTION}

$\mathrm{O}$ ne of the cornerstones of the management of inflammatory bowel disease (IBD) is the use of 5-aminosalicylic acid (5-ASA) compounds (i.e., mesalamine, sulfasalazine, olsalazine, balsalazide) for treatment of IBD flares and maintenance of remission. ${ }^{1}$ As gastrointestinal anti-inflammatory agents, 5-ASA compounds act locally in the colon to modulate the inflammatory response induced by the IBD process. The exact mechanism of action of 5-ASA remains to be fully elucidated; however, it is thought that its ability to modulate inflammatory cytokine production and inhibit prostaglandin and leukotriene biosynthesis contributes to its clinical effect. ${ }^{2}$ The efficacy and safety of 5-ASA derivatives in the management of IBD have been demonstrated in several clinical trials, and the use of these agents remains one of the main pharmacotherapeutic options for patients suffering from this

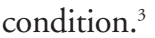

One concern regarding the use of 5-ASA compounds is their potential unsuitability for patients with IBD and a prior history of acetylsalicylic acid (ASA) hypersensitivity. 5-ASA compounds share a structural similarity with ASA, differing only by the presence of an amino group at position 5 of the benzene ring. As a result, there are concerns regarding potential cross-reactivity between 5-ASA and ASA. Such concerns are apparent in the 5-ASA product monographs, which caution against the use of these compounds in individuals with salicylate sensitivity. ${ }^{4}$

The incidence of ASA sensitivity reactions is estimated at $0.07 \%$ to $0.3 \%$ for the general population; however, this rate increases to $4.3 \%$ to $21 \%$ among adults with asthma. ${ }^{5}$ Hypersensitivity reactions to ASA and/or nonsteroidal antiinflammatory drugs (NSAIDs) induced by immunoglobulin $\mathrm{E}$ (IgE)-mediated pathways (characterized by the development of symptoms of anaphylaxis, including urticaria, angioedema, bronchospasm, and/or hypotension) have been reported, but these reports are relatively rare. ${ }^{5}$ Most reactions induced by ASA or NSAID (e.g., ASA-exacerbated respiratory disease, ASA-induced urticaria or angioedema) are due to the inhibition of the cycloxygenase-1 (COX-1) enzyme and subsequent release of histamine and synthesis of leukotrienes. ${ }^{6}$ The challenge to a clinician arises when a patient has a history of
ASA sensitivity and requires treatment with 5-ASA compounds for IBD, as there is a paucity of information to guide decisionmaking in this situation. This review attempts to address this information gap and evaluates the available literature to determine whether the use of 5-ASA derivatives is a feasible therapy for patients with documented sensitivity to ASA or NSAIDs.

\section{LITERATURE REVIEW}

A literature search of MEDLINE (1946 to January Week 1, 2013) and Embase (1974 to 2013 Week 01) was conducted using the following terms: "sulfasalazine", "aminosalicylic acids", "mesalamine", "olsalazine", "balsalazide", "5-ASA", "aspirin", "nonsteroidal anti-inflammatory agents", "ASA", "NSAID”, "acetylsalicylic", "hypersensitivity", "immunoglobulin E", "hypersensitivity (immediate)", "hypersensitivity (delayed)", "allergy", "intolerance", "sensitivity", and "drug hypersensitivity". Included articles were restricted to those published in English. In addition, the references of relevant articles were reviewed for relevant citations. A total of 485 citations were identified in the initial search. Of these, 481 were excluded, because they did not examine the use of 5-ASA in individuals with ASA sensitivity. The 4 articles that were eligible for further review were all case reports ${ }^{7-10}$ (see Table 1).

In the first case $^{7}$ mesalamine was initiated for a 73 year-old woman with ulcerative colitis and a history of ASA sensitivity. The patient reported tongue and throat swelling associated with ingestion of ASA, but she had been able to manage the reaction by discontinuing ASA and using antihistamines. She had not required hospitalization for the reaction. There was no history of asthma, hay fever, or other allergic disorders. Because of her history of an adverse reaction to ASA, a test dose of mesalamine $1000 \mathrm{mg}$ was administered orally under a physician's supervision. The patient experienced no adverse effects with this dose. Subsequently, a therapeutic dose of mesalamine ( $3.6 \mathrm{~g} /$ day $)$ was prescribed, and she tolerated the medication well.?

In another case, ${ }^{8}$ mesalamine therapy was successfully initiated, after a 3-day desensitization period, for a 28-year-old woman with Crohn disease and sensitivities to both ASA and 
This single copy is for your personal, non-commercial use only.

For permission to reprint multiple copies or to order presentation-ready copies for distribution, contact CJHP at cjhpedit@cshp.ca

Table 1. Case Reports of 5-ASA Use in Patients with Documented ASA Sensitivity

\begin{tabular}{|c|c|c|c|c|c|}
\hline Study & Age and Sex* & $\begin{array}{c}\text { Dose and Duration } \\
\text { of 5-ASA }\end{array}$ & $\begin{array}{c}\text { Nature of ASA } \\
\text { or NSAID } \\
\text { Sensitivity }\end{array}$ & $\begin{array}{l}\text { ASA or NSAID } \\
\text { Sensitivity } \\
\text { Confirmed? }\end{array}$ & Outcome \\
\hline Murphy et al. ${ }^{7}$ & 73-year-old female & $\begin{array}{l}\text { Mesalamine } 3.6 \mathrm{~g} \\
\text { daily for } 10 \text { months }\end{array}$ & $\begin{array}{l}\text { Tongue, throat } \\
\text { swelling secondary } \\
\text { to ASA use }\end{array}$ & No & $\begin{array}{l}\text { Successful use of } \\
\text { mesalamine }\end{array}$ \\
\hline $\begin{array}{l}\text { Paraskevopoulos } \\
\text { et al. }{ }^{8}\end{array}$ & 28-year-old female & $\begin{array}{l}\text { Mesalamine } \\
1000 \mathrm{mg} 3 \text { times } \\
\text { daily, unknown } \\
\text { duration }\end{array}$ & $\begin{array}{l}\text { Generalized urticaria, } \\
\text { facial angioedema } \\
\text { secondary to ASA } \\
\text { use }\end{array}$ & No & $\begin{array}{l}\text { Successful use of } \\
\text { mesalamine after } \\
\text { mesalamine } \\
\text { desensitization }\end{array}$ \\
\hline Vernon et al. ${ }^{9}$ & 9-year-old male & $\begin{array}{l}\text { Sulfasalazine } \\
500 \text { mg, unknown } \\
\text { frequency, unknown } \\
\text { duration }\end{array}$ & $\begin{array}{l}\text { Facial angioedema } \\
\text { secondary to } \\
\text { ibuprofen use }\end{array}$ & No & $\begin{array}{l}\text { Successful use of } \\
\text { sulfasalazine after } \\
\text { sulfasalazine } \\
\text { desensitization }\end{array}$ \\
\hline Kung et al. ${ }^{10}$ & 27-year-old male & $\begin{array}{l}\text { Mesalamine, } \\
\text { unknown frequency, } \\
\text { variable duration }\end{array}$ & $\begin{array}{l}\text { Tolerated ASA } \\
\text { previously }\end{array}$ & NA & $\begin{array}{l}\text { Successful use of } \\
\text { balsalazide after } \\
\text { balsalazide } \\
\text { desensitization }\end{array}$ \\
\hline
\end{tabular}

5-ASA = 5-aminosalicylic acid, ASA = acetylsalicylic acid, NA = not applicable.

*Ethnic background was not reported for any of the patients.

mesalamine. The patient reported 2 episodes of generalized urticaria and facial angioedema occurring $1 \mathrm{~h}$ after administration of ASA. For each episode, hospitalization was required. There was no history of bronchial asthma or nasal polyps. A single-blind, placebo-controlled oral challenge to mesalamine was initiated, and $45 \mathrm{~min}$ after the third dose of mesalamine $(250 \mathrm{mg})$, the patient experienced generalized urticaria with pruritus. The patient was treated with intramuscular chlorpheniramine and hydrocortisone and recovered within 90 min. As a result of this reaction, a mesalamine desensitization protocol was undertaken, with successful completion to target mesalamine $1000 \mathrm{mg} 3$ times a day. ${ }^{8}$ This was the first published report of a patient with reported ASA sensitivity who experienced a reaction to mesalamine. However, the authors were unable to demonstrate an IgE-mediated mechanism for both ASA and mesalamine, and the patient was not challenged with a test dose of ASA or NSAID to confirm the validity of her prior ASA reactions.

In a pediatric case report, ${ }^{9}$ investigators reported successful sulfasalazine desensitization in a 9-year-old boy with CHARGE association (a constellation of genetic abnormalities characterized by coloboma of the eye, heart defects, atresia of the nasal choanae, retardation of growth and/or development, genital and/or urinary abnormalities, and ear abnormalities and deafness) and a remote history of facial angioedema after use of an NSAID (ibuprofen) at 2 years of age. The patient underwent sulfasalazine desensitization starting at $0.1 \mathrm{mg}$ and was able to tolerate a therapeutic dose of $500 \mathrm{mg}$ of oral sulfasalazine with no adverse reactions. ${ }^{9}$ The limitations of this case report included no investigation of the patient's remote history of NSAID allergy and no oral challenge to sulfasalazine before initiation of the desensitization protocol; also, use of a desensitization protocol may have obscured a potential reaction to sulfasalazine.

In the fourth case report, ${ }^{10}$ a 27 -year-old man with Crohn disease experienced a generalized, nonpruritic papular rash associated with lip and pedal edema without systemic symptoms while taking mesalamine. This patient had previously reported ingestion of ASA with no untoward effects. The patient underwent successful graded challenge with balsalazide with no adverse effects. ${ }^{10}$

\section{DISCUSSION}

This review of 5-ASA use in patients with sensitivity to ASA or NSAID had several limitations. All of the articles found in the literature search were case reports, ${ }^{7-10}$ and the nature and validity of the ASA or NSAID sensitivity were not verified in any of these cases. In addition, the decision to initiate a 5-ASA desensitization protocol pre-emptively may have ameliorated any reaction to 5-ASA. Furthermore, the articles did not address the possibility of any other confounding factors that could have contributed to the reaction observed during administration of ASA or NSAID. In the case of the 28-yearold woman with an observed reaction to mesalamine, ${ }^{8}$ the report did not state whether other factors that could have influenced the observed reaction (e.g., concurrent exposure to other medications or environmental factors) were ruled out. Although the literature search covered MEDLINE and Embase, some studies or case reports may have been missed if they were indexed incorrectly or did not use the key terms used in the search described above.

Despite the structural similarity between ASA and 5-ASA, there is a lack of evidence demonstrating cross-reactivity between the 2 compounds. The lack of evidence does not prove 
an absence of cross-reactivity, but a possible hypothesis for this phenomenon may relate to the mechanism of action of 5-ASA. In vitro experiments with 5-ASA compounds have led to several proposed mechanisms of action, one of which suggests that the ability of 5-ASA compounds to control inflammation may be due to their capability to activate the $\gamma$ form of peroxisome proliferator-activated receptors in colon epithelial cells. These receptors are involved in the control of inflammation, cell proliferation, apoptosis, and metabolic function. ${ }^{11}$ Another hypothesis is that the anti-inflammatory effect of 5-ASA is due to its ability to inhibit the cyclo-oxygenase and lipo-oxygenase pathways, leading to the inhibition of prostaglandin E2 and leukotrienes, respectively. ${ }^{12}$ Thus, the anti-inflammatory effect of 5-ASA is unlike that of ASA and nonselective NSAIDs; as discussed earlier, ASA- and NSAIDinduced reactions (ASA-exacerbated respiratory disease, ASAinduced urticaria or angioedema) are due to the inhibition of the COX-1 enzyme and subsequent release of histamine and synthesis of leukotrienes, a mechanistic phenomenon that has not been observed with 5-ASA.

In addition, true IgE hypersensitivity to ASA or NSAIDs is rare, and although limited clinical data exist, patients who experience an IgE-mediated reaction to a specific NSAID will not have a cross-reaction with other nonselective NSAIDs, as previous exposure to the drug is required for the production of drug-specific IgE antibodies. ${ }^{4}$ This phenomenon may be true with ASA or NSAIDs and 5-ASA as well; however, it remains an unproven hypothesis.

\section{CONCLUSIONS}

Avoidance of 5-ASA compounds in patients with IBD who have a history of ASA sensitivity limits the possible pharmacotherapy options, which might be detrimental to successful management of this condition. The literature regarding the safety of 5-ASA derivatives in patients with sensitivity to ASA or NSAID is scant; the successful use of 5-ASA derivatives in ASA- or NSAID-sensitive patients has been reported, and the report of a patient tolerating ASA but not 5 -ASA ${ }^{10}$ suggests that cross-reactivity between these 2 classes of medications is unlikely. However, these reports are limited by the lack of information regarding the validity of prior reactions to ASA or NSAID in the patients described. In addition, the hypothesized anti-inflammatory effects of 5-ASA via inhibition of leukotrienes is contrary to the effects of ASA and NSAIDs, in which the release of histamines and synthesis of leukotrienes are major contributing factors in the initiation of the ASA- or NSAID-induced reactions.

Further reports describing the safety of 5-ASA use in ASAor NSAID-sensitive patients are needed before safety in this situation can be definitively determined. Therefore, pending further information, for patients with IBD reporting a prior history of ASA or NSAID sensitivity, 5-ASA compounds should not be ruled out as a pharmacotherapeutic option until a thorough investigation of the nature of the patient's sensitivity and possible test-dosing of 5-ASA are completed.

\section{References}

1. Mowat C, Cole A, Windsor A, Ahmad T, Arnott I, Driscoll I, et al.; IBD Section of British Society of Gastroenterology. Guidelines for the management of inflammatory bowel disease in adults. Gut. 2011;60(5):571-607.

2. Bosworth B, Scherl EJ. 5-ASAs in the treatment of iflammatory bowel disease. Gastroenterol Endosc News. 2011 Jul [cited 2013 Jan 7]. Available from: www.gastroendonews.com/download/5asa_gen0711_wm.pdf

3. Gisbert JP, Gomollón F, Maté J, Pajares JM. Role of 5-aminosalicylic acid (5-ASA) in treatment of inflammatory bowel disease: a systematic review. Dig Dis Sci. 2002;47(3):471-88.

4. Mesalamine (Salofalk) [product information]. Mont-Saint-Hilaire (QC): Axcan Pharma; 2004 Sep.

5. Knowles SR, Drucker AM, Weber EA, Shear NH. Management options for patients with aspirin and nonsteroidal antiinflammatory drug sensitivity. Ann Pharmacother. 2007;41(7):1191-200.

6. Berges-Gimeno MP, Stevenson DD. Nonsteriodal anti-inflammatory drug-induced reactions and desensitization. J Asthma. 2004;41(4):375-84.

7. Murphy SJ, Mayer L, Abreu MT. Mesalamine (5-aminosalicylic acid) therapy well tolerated in a patient with aspirin hypersensitivity and ulcerative colitis [letter]. J Clin Gastroenterol. 2011;45(1):83-4.

8. Paraskevopoulos I, Konstantinou G, Liatsos C. Desensitization treatment of an aspirin- and mesalamine-sensitive patient with Crohn's disease [letter]. Inflamm Bowel Dis. 2005;11(4):417-8.

9. Vernon N, Deshpande K, Jariwala S, Shliozberg J. Sulfasalazine desensitization in the setting of NSAID allergy [abstract]. Ann Allergy Asthma Immunol. 2011;107(5 Suppl):A56. Also available from: http:// dx.doi.org/10.1016/j.anai.2011.09.019 (subscription or payment required to access content).

10. Kung SJ, Choudhary C, McGeady SJ, Cohn JR. Lack of cross-reactivity between 5-aminosalicylic acid-based drugs: a case report and review of the literature. Ann Allergy Asthma Immunol. 2006;97(3):284-7.

11. Desreumaux P, Ghosh S. Review article: mode of action and delivery of 5-aminosalicyclic acid-new evidence. Aliment Pharmacol Ther. 2006; 24 Suppl 1:2-9.

12. Sonu R, Lin MV, Blonski W, Lichtenstein GR. Clinical pharmacology of 5-ASA compounds in inflammatory bowel disease. Gastroenterol Clin North Am. 2010;39(3):559-99.

Jennifer Poh, BScPhm, PharmD, was, at the time of writing, a Doctor of Pharmacy student with the Leslie Dan Faculty of Pharmacy, University of Toronto, Toronto, Ontario. She is now a Clinical Pharmacist in General Pediatrics and Respirology at the Hospital for Sick Children, Toronto, Ontario.

Sandra Knowles, BScPhm, is a Drug Policy Research Specialist with the Ontario Drug Policy Research Network, St Michael's Hospital, Toronto, Ontario.

Competing interests: None declared.

Address correspondence to:

Jennifer Poh

Hospital for Sick Children

555 University Avenue

Toronto ON M5G 1X8

e-mail: jennifer.poh@utoronto.ca 